\title{
Magnitude of elevated iron stores and risk associated in steady state sickle cell anemia Congolese children: a cross sectional study
}

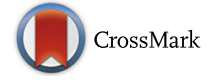

\author{
Jean-Robert Makulo ${ }^{1 *}$, Karen Efombola Itokua ${ }^{2}$, Rosette Kevani Lepira ${ }^{2}$, Gloire Mavinga Bundutidi ${ }^{2}$, \\ Michel Ntetani Aloni ${ }^{2}$, René Makuala Ngiyulu' ${ }^{2}$, Jean Lambert Gini ${ }^{2}$ and François Bompeka Lepira ${ }^{1}$
}

\begin{abstract}
Background: The serum ferritin assay is recommended in Sickle Cell Anemia (SCA) patients receiving regular transfusions. According to several authors, elevated iron stores indicating iron chelation corresponds to hyperferritinemia $\geq 500 \mathrm{ng} / \mathrm{ml}$, and becomes detectable after twenty blood transfusions. The objectives of the study were to determine the prevalence of elevated iron stores and identify associated risk factors in a case series of Steady state SCA Congolese children.

Material and methods: Serum ferritin was assayed in Steady state SCA children followed in 2 specialized hospitals in Kinshasa. Elevated iron stores was defined as serum ferritin level $\geq 500 \mathrm{ng} / \mathrm{ml}$, and the associated risk factors were identified using univariate analysis.

Results: Seventy patients (median age 9 years, $56 \%$ boys, $53 \%$ receiving hydroxyurea) were selected in the study. Serum ferritin levels ranged from 24 to $2584 \mathrm{ng} / \mathrm{ml}$ with $21.4 \%$ of children having elevated iron stores. Mean levels of $\mathrm{LDH}$, indirect bilirubin, plasma free $\mathrm{Hb}$ and CRP were similar between the 2 groups whereas history of polytransfusions (> 3 during the last year) was more frequent among patients with elevated iron stores (73\% vs. $44 \%, p=0.078$ ). Receiving $>3$ transfusions in a year vs. 0 was the main risk factor associated with elevated iron stores [OR 6.17 (95\% Cl: 1.81-20.96)].

Conclusion: In SCA children, hyperferritinemia requiring iron chelation is most strongly related to blood transfusion. This situation concerned almost one in five children in present study; this shows the magnitude of the problem which is underestimated.
\end{abstract}

Keywords: Sickle cell anemia, Elevated iron stores, Polytransfusions, DR Congo

\section{Introduction}

Sickle cell anemia (SCA) is the most common genetic disease in populations of African descent [1]. According to African regions and tribes, the homozygous form affects 1 to $2 \%$ of live births, whereas the heterozygous form can affect 10 to $35 \%$ of individuals $[2,3]$. The hyperhemolytic crisis, one of the most common complications of this disease, usually requires urgent transfusion therapy, which

* Correspondence: jrmakulo2016@gmail.com

${ }^{1}$ Division of Nephrology, Nephrology Unit, Department of Internal Medicine, University Hospital of Kinshasa, Faculty of Medicine, University of Kinshasa, Kinshasa XIPO.BOX 123Democratic Republic of Congo

Full list of author information is available at the end of the article exposes to iron overload since each transfused red blood cell provides about $200 \mathrm{mg}$ of iron [4].

The management of sickle cell disease guidelines (The National Heart Lung and Blood Institute) recommends monitoring and treatment of iron overload in any patient who is regularly transfused [5]. Serum ferritin is the most frequently used test to estimate iron overload [5]. In steady state, several studies show a significant correlation between total transfused units by simple top-up and serum ferritin [6]. For the World Health Organization (WHO), the risk of iron overload in patients over 5 years-of-age is elevated beyond $200 \mathrm{ng} / \mathrm{ml}$ [7]. However, organic lesions may occur at ferritin levels

(c) The Author(s). 2019 Open Access This article is distributed under the terms of the Creative Commons Attribution 4.0 International License (http://creativecommons.org/licenses/by/4.0/), which permits unrestricted use, distribution, and reproduction in any medium, provided you give appropriate credit to the original author(s) and the source, provide a link to the Creative Commons license, and indicate if changes were made. The Creative Commons Public Domain Dedication waiver (http://creativecommons.org/publicdomain/zero/1.0/) applies to the data made available in this article, unless otherwise stated. 
above $1000 \mathrm{ng} / \mathrm{ml}$, and some authors recommend chelation as soon as ferritin levels exceed $500 \mathrm{ng} / \mathrm{ml}$ [8].

The Democratic Republic of the Congo (DRC) has the third highest population of SCA patients in the world after Nigeria and India. However, SCA is not yet really regarded as a healthcare priority, despite WHO resolution [9]. Children with SCA are known to have an increased risk of blood transfusion and iron overload, especially in areas with holoendemic malaria like the DRC. Previous studies have reported that transfusions because of severe anaemia have been necessary in children with SCA [10-13]. Despite these high prevalence, few studies focused on the assessment of iron homeostasis in steady state SCA children. The dosage of ferritin for SCA is not common practice in DRC and is only possible in a few major health institutions in the country, meaning that diagnosis of iron overload and its organ damage are underestimated and delayed. In our midst, Tshilolo et al. reported that $35 \%$ of homozygous sickle cell children had ferritin levels above $300 \mathrm{ng} / \mathrm{ml}$ [14]. However, the number of those who require iron chelation is unknown. The objectives of this study were to estimate the prevalence of elevated iron stores and to identify the associated risk factors in a population of SCA children followed in 2 hospitals in Kinshasa specialized in the management of Sickle cell disease.

\section{Material and methods}

The present study is a post-hoc analysis that uses the results of an oxidative stress study in homozygous SCA Congolese children whose methodological procedures have been detailed in previous publications $[15,16]$. Briefly, SCA children between 2 and 18 years-of-age consecutively followed in two hospitals in the country's capital Kinshasa, namely the Centre Médical Monkole and the Saint-Crispin Medical were selected for the period from 15 June, 2014 to 30 August, 2014. These health facilities are specialized in the care management of SCA. Only Steady state children (exlusion of SCA children who were transfused, hospitalized and had a major vaso-occlusive crisis within the last 2 months before the study) had been selected. Children with a history of liver disease or chronic alcoholism were excluded.

Serum ferritin $(\mathrm{ng} / \mathrm{ml})$ was assayed by the enzyme immunoassay using a Mini vidas ${ }^{\circ}$ device (BioMérieux, France). The blood count, total and direct bilirubin, assay of $\mathrm{C}$ reactive protein (CRP), lactate dehydrogenase (LDH) and serum iron were performed using a Cobas $\mathrm{C} 111^{\circ}$ device (Roche, Switzerland). Plasma free hemoglobin $(\mathrm{Hb})$ was assayed spectrophotometrically using a Genesys $20^{\circ}$ device (Thermo Fisher Scientific, USA). In the present study, elevated iron stores (hyperferritinemia) was defined as $\geq 500 \mathrm{ng} / \mathrm{ml}$ [8]. The normal rates of serum iron were defined as values between 10 and $30 \mu \mathrm{mol} / \mathrm{l}$.

\section{Ethical approval}

Ethical approval for the study was granted by the institutional review boards of the Centre Médical Monkole (006 CEFA-MONKOLE/2014) in line with the principles of the Declaration of Helsinki, second revision. The aim and study procedures were explained to the parents or legal guardians and they provided written consent before any of the subjects where included.

\section{Statistical analysis}

Comparisons of groups were analyzed using the Chi Square test or Fisher Exact test for the categorical variables, and the Student or Mann Whitney tests for the numerical variables according to whether the distribution of the variables was Gaussian or not Gaussian. The risk factors associated with elevated iron stores were investigated in univariate analysis and considered significant at the $5 \%$ level of significance $(p<0.05)$. We performed logistic regression analysis which evaluated the following variables: lack of hydrea, inflammatory satus (CRP $>6 \mathrm{mg} / \mathrm{l}$ and $\mathrm{CRP}>12 \mathrm{mg} / \mathrm{l}$ ), hemolytic status ( $\mathrm{LDH}>$ median value and plasma free $\mathrm{Hb}>$ median value), age $>5$ years and receiving transfusions vs 0 transfusion in a year.

\section{Results}

A total of 70 SCA children (56\% boys, $53 \%$ receiving hydroxyurea $=\mathrm{HU}$ ) were selected. Their median age was 9 years with an interquartile range (IQR) of 6 to 13 years. In the past 12 months, half of children $(50 \%)$ had received more than 3 transfusions, 37\% had received $1-3$ transfusions, and 13\% had not been transfused (Table 1).

Ferritin levels ranged from 24 to $2584 \mathrm{ng} / \mathrm{ml}$. Serum ferritin levels $\geq 500 \mathrm{ng} / \mathrm{ml}$ and $\geq 1000 \mathrm{ng} / \mathrm{ml}$ were found in 15 children (21.4\%) and 4 children (5.7\%), respectively. Among children with serum ferritin levels $\geq 500 \mathrm{ng} / \mathrm{ml}$, 93.3\% had normal iron level while 29 and $14 \%$ of them had CRP level $\geq 6 \mathrm{mg} / \mathrm{l}$ and $\geq 12 \mathrm{mg} / \mathrm{l}$, respectively. Polytransfusion ( $>3$ in the last 12 months) was associated with hyperferritinemia $\geq 500 \mathrm{ng} / \mathrm{l}$; high CRP levels appeared to be associated with hyperferritinemia, but the difference was not statistically significant (Table 2).

Figure 1 shows that in the whole group, serum ferritin levels increased proportionally with the number of blood transfusions received during the last year; median values of serum ferritin levels were $125 \mathrm{ng} / \mathrm{ml}$ in the group 1 (IQR: $99-185 \mathrm{ng} / \mathrm{ml}$ ), $222 \mathrm{ng} / \mathrm{ml}$ in the group 2 (IQR: $102-453 \mathrm{ng} / \mathrm{ml}$ ), and $301 \mathrm{ng} / \mathrm{ml}$ in the group 3(IQR: $123-747 \mathrm{ng} / \mathrm{ml})(p=0.010)$.

Receiving 1-3 transfusions in a year vs. 0 [OR 3.08 (95\% CI: $1.06-8.97)]$ and $>3$ transfusions in a year vs. 0 [OR 6.17 (95\% CI: 1.81-20.96)] were the only two risk factors of elevated iron stores retained in univariate analysis. 
Table 1 Clinical and biological profile of the study population

\begin{tabular}{|c|c|c|c|c|}
\hline & Whole group & $\begin{array}{l}\text { male } \\
n=39\end{array}$ & $\begin{array}{l}\text { female } \\
n=31\end{array}$ & $p$ \\
\hline Age, years & $9(6-13.3)$ & $10(7-14)$ & $9(5-12)$ & 0.789 \\
\hline Transfusions > 3/year & $35(50)$ & $23(59)$ & $12(39)$ & 0.189 \\
\hline 1-3/year & $26(37)$ & $13(33)$ & $13(42)$ & \\
\hline 0/year & $9(13)$ & $3(8)$ & 6(19) & \\
\hline $\mathrm{WBC} / \mathrm{mm}^{3}$ & $11.618 \pm 4.621$ & $11.339 \pm 4.114$ & $12.011 \pm 5.311$ & 0.568 \\
\hline Platelets $\times 10^{3} / \mathrm{mm}^{3}$ & $380.727 \pm 154.522$ & $364.359 \pm 132.846$ & $401.884 \pm 184.553$ & 0.344 \\
\hline Reticulocytes, \% & $12.0(8.5-17.6)$ & $11.0(8.5-18.0)$ & $13.0(8.0-17.8)$ & 0.799 \\
\hline CRP, mg/l & $3.43(2.01-5.07)$ & $3.44(2.52-5.99)$ & $3.36(1.88-5.01)$ & 0.891 \\
\hline $\begin{array}{l}\text { Total Bilirubin, mg/dl } \\
\text { Indirect Bilirubin, mg/dl }\end{array}$ & $\begin{array}{l}1.9(1.5-3.5) \\
1.9(0.9-3.5)\end{array}$ & $\begin{array}{l}2.5(1.6-4.2) \\
1.9(1.0-3.6)\end{array}$ & $\begin{array}{l}1.9(1.5-3.5) \\
1.3(0.9-3.2)\end{array}$ & $\begin{array}{l}0.841 \\
0.823\end{array}$ \\
\hline Direct Bilirubin, mg/dl & $0.5(0.4-0.7)$ & $0.6(0.4-0.7)$ & $0.5(0.4-0.7)$ & 0.680 \\
\hline LDH, UI/I & $544(400-771)$ & $550(424-795)$ & $516(375-686)$ & 1.000 \\
\hline Serum iron, $\mu \mathrm{mol} / \mathrm{l}$ & $16.2(13.2-19.2)$ & $16.2(13.6-19.0)$ & $16.3(11.7-20.3)$ & 0.941 \\
\hline Serum ferritin, ng/ml & 209(106-453) & $184(97-440)$ & $213(106-519)$ & 0.891 \\
\hline Free plasma Hb, mg/l & $168(116-267)$ & 168(110-282) & $160(120-244)$ & 0.950 \\
\hline
\end{tabular}

Record values are expressed as absolute frequency (\%), mean \pm standard deviation or median (IQR 25-75)

Abbreviations: WBC white blood cells, CRP C reactive protein, $L D H$ Lactate dehydrogenase, $H b$ hemoglobin

\section{Discussion}

The present study showed that approximately one in five homozygous SCA children had hyperferritinemia level requiring iron chelation. Multiple blood transfusions emerged as the only determinant of elevated iron stores.
In SCA, elevated serum ferritin levels may reflect inflammatory syndrome, hemolysis or transfusion therapy [17]. In the present study, only patients who were in steady state over the last 2 months were selected suggesting a likely reduced impact of inflammation and

Table 2 Serum Ferritin level-based characteristics of SCA children

\begin{tabular}{|c|c|c|c|}
\hline & \multicolumn{2}{|l|}{ Serum ferritin } & \multirow[t]{2}{*}{$p$} \\
\hline & $<500 \mathrm{ng} / \mathrm{ml}(n=55)$ & $\geq 500 \mathrm{ng} / \mathrm{ml}(n=15)$ & \\
\hline male, \% & $31(57)$ & $8(53)$ & $0.976^{*}$ \\
\hline Age $<5$ years, $\%$ & 10(18) & $5(33)$ & $0.286^{*}$ \\
\hline $\mathrm{HU}, \%$ & $26(48)$ & $10(67)$ & $0.247^{*}$ \\
\hline Major VOC $\geq 2 / a n, \%$ & $6(11)$ & $3(20)$ & $0.391^{*}$ \\
\hline Transfusions > 3/year, \% & $24(44)$ & $11(73)$ & $0.078^{*}$ \\
\hline Hct, \% & $22.4(20.7-24.8)$ & $22.4(19.0-28.1)$ & 0.903 \\
\hline Platelets $\times 10^{3} / \mathrm{mm}^{3}$ & $387(293-472)$ & $288(172-427)$ & 0.239 \\
\hline WBC, $\times 10^{3}$ élts $/ \mathrm{mm}^{3}$ & $11.5(8.4-14.6)$ & $9.9(7.2-17.6)$ & 0.951 \\
\hline Reticulocytes, \% & $11.9(8.0-17.0)$ & $13.0(9.5-23.3)$ & 0.964 \\
\hline CRP, mg/l & $3.4(2.0-4.8)$ & $3.8(2.3-8.5)$ & 0.764 \\
\hline $\mathrm{CRP} \geq 6 \mathrm{mg} / \mathrm{l}, \%$ & $7(13)$ & $4(29)$ & $0.233^{*}$ \\
\hline $\mathrm{CRP} \geq 12 \mathrm{mg} / \mathrm{l}, \%$ & $3(5)$ & $2(13)$ & $0.290^{*}$ \\
\hline Indirect Bilirubin, mg/dl & $1.9(1.0-3.6)$ & $1.3(0.9-2.0)$ & 0.547 \\
\hline LDH, UI/I & $568(424-771)$ & $488(320-782)$ & 0.559 \\
\hline Free plasma $\mathrm{Hb}, \mathrm{mg} / \mathrm{l}$ & $183(123-282)$ & $130(107-205)$ & 0.479 \\
\hline Serum iron, $\mu \mathrm{mol} / / \mathrm{l}$ & $16.1(12.4-19.5)$ & $16.8(14.9-19.9)$ & 0.849 \\
\hline
\end{tabular}

Record values expressed as frequency or median (IQ 25-75)

Abbreviations: Hct: hematocrit, WB: white blood cells, CRP: Creactive protein, LDH: Lactate dehydrogenase, $H b$ : hemoglobin, $H U$ : hydroxyurea, VOC:

vaso-occlusive crisis

*Fisher Exact test 


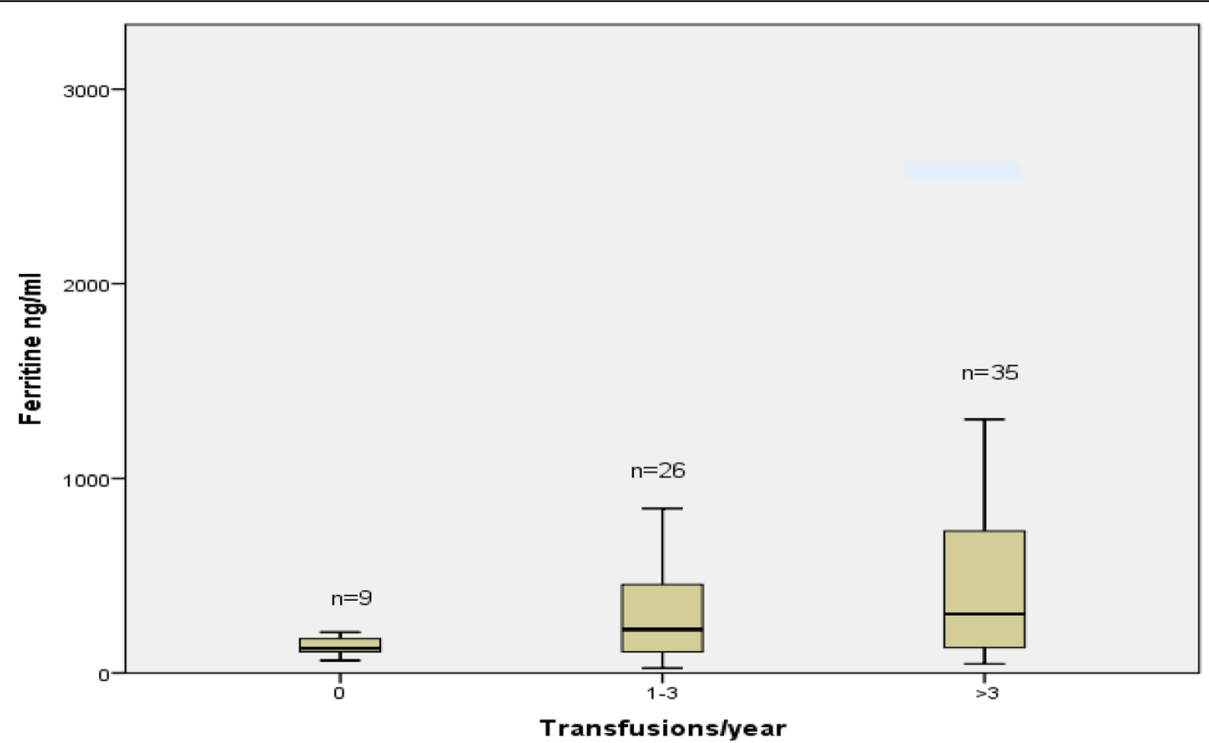

Fig. 1 Variation of serum ferritin level as a function of the number of transfusions during the last 12 months

hemolysis on measured ferritin levels. Furthermore, many studies have reported that increases in serum ferritin levels induced by inflammatory and hemolysis states are usually moderate $(<500 \mathrm{ng} / \mathrm{ml}) \quad[17,18]$. Higher rates of serum ferritin levels can be seen in alcoholism and some liver diseases not present in our case series [19].

According to several authors, iron overload becomes detectable after 20 blood transfusions [20]. Almost half of our patients and / or their tutors were unable to accurately recall the number of transfusions received since birth, so this assessment was not possible. However, our results indicate that, regardless of the number of blood transfusions received in previous years, children with more than three blood transfusions during the year, experienced elevated iron stores. In a previous Congolese study, Tshilolo et al. showed that the average blood transfusion requirement was 0.4 units per patient-year in Congolese SCA patients [11]. However, our finding need to be strengthen by taking into account of other confounders such as the exact volume of blood received by each patient, the nature of transfused blood (whole blood, red blood cell, single transfusions or erythrapheresis), initial iron status and co-morbidities. Unfortunately, these factors were not available in this post-hoc analysis.

The cumulative and deleterious effects of blood transfusions on iron overload rely upon iron metabolism. Indeed, iron has been reported to lack a physiologic system of elimination exposing it to cumulate in case of increased intake. Thus, during transfusion of red blood cell, nearly $200 \mathrm{mg}$ of iron reach the body; however, every day barely $1 \mathrm{mg}$ of iron is eliminated through the skin and intestinal epithelial: iron is thus eliminated very slowly $[4,20,21]$. The complete saturation of transferrin and ferritin facilitates the binding of iron to other circulating molecules, the basis for the accumulation of reactive iron complexes within parenchymal cells [21]. During the transfer of electrons between iron molecules of different valences $(\mathrm{Fe} 3+$ and $\mathrm{Fe} 2+)$, extremely reactive free radicals are formed with subsequent oxidative damage of tissues and organs [21, 22].

The frequency of the elevated iron stores ranges from 22 to $41.5 \%$ in African studies [11, 14, 23-25]. These differences in the relative proportions of elevated iron stores between these studies presumably arise from differences in the definition of hyperferritinemia, age of the study population, environmental, immunologic and genetic factors that influence iron status in sickle cell population. These situations strongly suggest that more research in African countries would provide valuable insights into the pathogenesis of iron overload as reported in a recent Egyptian cohort [26].

Failure to perform liver biopsy to assess iron overload constitutes a limitation of the present study. In the absence of this invasive technique, imaging techniques such as magnetic resonance and Superconducting Quantum Interference Device (SQUID) have been reported to provide a good correlation between iron tissue concentrations and potential organic damage [27]. However, as a general rule, the serum ferritin concentration assay offers an interesting alternative. Indeed, several studies have shown a linear correlation between serum ferritin levels and total body iron load, based on the results of the assessment of hepatic iron concentration by biopsy analysis $[5,7,8]$.

Considering the results of this study, local physicians should be sensitized to avoid iterative transfusions by 
respecting the indications for blood transfusion in SCA, to perform serum ferritin test, in particular from more than 3 blood transfusions during the year. Indications of iron chelation therapy must be known and systematized to prevent comorbidities associated with iron overload.

\section{Conclusion}

In SCA children, hyperferritinemia requiring iron chelation is most strongly related to blood transfusion. This situation concerned almost one in five children in present study; this shows the magnitude of the problem which is underestimated.

\section{Abbreviations}

CRP: C reactive protein; Hb: Hemoglobin; Hct: Hematocrit; HU: Hydroxyurea; LDH: Lactate dehydrogenase; SCA: Sickle cell anemia; VOC: Vaso-occlusive crisis.; WBC: White blood cell

\section{Acknowledgements}

We are grateful to the laboratory technicians of the Centre Hospitalier Mère et Enfants de Monkole, Centre Hospitalier Saint-Crispin and the School of Public Health of the University of Kinshasa for the analyses of the samples.

\section{Funding}

This work received no financial assistance from any funding agency in the public, commercial or non-profit sectors.

\section{Availability of data and materials}

The datasets used and/or analysed during the current study are available from the corresponding author on reasonable request.

\section{Authors' contributions}

KEl participated in the design, data collection and writing of the manuscript. JRM and FBL were involved in the design and writing of the manuscript. GMB participated in the data collection and writing of the manuscript. RKL, MNA, RMN and JLG participated in the design and writing of the manuscript. All authors read and approved the final manuscript.

\section{Ethics approval and consent to participate}

Ethical approval for the study was granted by the institutional review boards of the Centre Médical Monkole (006 CEFA-MONKOLE/2014) in line with the principles of the Declaration of Helsinki, second revision. The aim and study procedures were explained to the parents or legal guardians and they provided written consent before any of the subjects where included.

\section{Consent for publication}

not applicable.

\section{Competing interests}

The authors have no conflicts of interest to disclose.

\section{Publisher's Note}

Springer Nature remains neutral with regard to jurisdictional claims in published maps and institutional affiliations.

\section{Author details}

'Division of Nephrology, Nephrology Unit, Department of Internal Medicine, University Hospital of Kinshasa, Faculty of Medicine, University of Kinshasa, Kinshasa XIPO.BOX 123Democratic Republic of Congo. ${ }^{2}$ Division of Hemato-Oncology and Nephrology, Department of Pediatric, University Hospital of Kinshasa, University of Kinshasa, Kinshasa, Democratic Republic of Congo.
Received: 28 July 2017 Accepted: 9 January 2019

Published online: 08 February 2019

\section{References}

1. Embury SH, Hebbel RP, Mohandas N, Steinberg MH. Sickle cell disease: Basic principles and clinical practice. Raven Press 1994; 311-326.

2. Tshilolo L, Aissi LM, Lukusa D. Neonatal screening for sickle cell anemia in the DR Congo: experience from a pioneer project on 31204 newborns. J Clin Pathol. 2009:62:35-8.

3. Dennis-Antwi JA, Dyson S, Ohene-Frempong K. Healthcare provision for sickle cell disease: challenges for the African context. Diversity in Health and Social Care. 2008;5:241-54

4. Andrews NC. Disorders of iron metabolism. N Engl J Med. 1999:341:1986-95.

5. National Institute of Health: National Heart, Lung, and Blood Institute, Division of Blood Diseases and Resources: The management of sickle cell disease. NHI Publications 2002; 02-2117.

6. Stanley HM, Friedman DF, Webb J, Kwiatkowski JL. Transfusional Iron overload in a cohort of children with sickle cell disease: impact of magnetic resonance imaging, transfusion method, and chelation. Pediatr Blood Cancer. 2016:63(8):1414-8.

7. OMS. Concentrations sériques de ferritine permettant d'évaluer le statut et les carences en fer dans les populations. Système d'informations nutritionnelles sur les vitamines et les minéraux. Genève. OMS, 2011.

8. Ballas SK. Iron overload is a determinant of morbidity and mortality in adult patients with sickle cell disease. Semin Hematol. 2001;38:30-6.

9. Piel FB, Hay SI, Gupta S, Weatherall DJ, Williams TN. Global burden of sickle cell anaemia in children under five, 2010-2050: modelling based on demographics, excess mortality and interventions. PLoS Med. 2013;10(7): e1001484

10. Aloni MN, Tshimanga BK, Ekulu PM, Ehungu JL, Ngiyulu RM. Malaria, clinical features and acute crisis in children suffering from sickle cell disease in resource-limited settings: a retrospective description of 90 cases. Pathog Glob Health. 2013:107(4):198-201.

11. Tshilolo LM, Mukendi RK, Wembonyama SO. Blood transfusion rate in Congolese patients with sickle cell anemia. Indian J Pediatr. 2007:74:735-8.

12. Aloni MN, Nkee L. Challenge of managing sickle cell disease in a pediatric population living in Kinshasa, Democratic Republic of Congo: a sickle cell center experience. Hemoglobin. 2014;38(3):196-200.

13. Kadima BT, Gini Ehungu JL, Ngiyulu RM, Ekulu PM, Aloni MN. High rate of sickle cell anaemia in sub-Saharan Africa underlines the need to screen all children with severe anaemia for the disease. Acta Paediatr. 2015;104(12): 1269-73.

14. Tshilolo L, Ngole ZM, Ngiyulu R, Kayembe ND. Iron status in 72 Congolese patients with sickle cell anemia. Med Sante Trop. 2016;26(1):83-7.

15. Itokua EK, Makulo JR, Lepira FB, Aloni MN, Ekulu PM, Sumaili EK, et al. Albuminuria, serum antioxidant enzyme levels and markers of hemolysis and inflammation in steady state children with sickle cell anemia. BMC Nephrol. 2016:17:178.

16. Itokua EK, Ngiyulu R, Makulo JR, Lepira BF, Aloni M, Sadiki H, et al. GPx and CU-Zn SOD activities in homozygous sickle cell Anemia: the primary role of hydroxyurea. Innov Res Health Sci Biotechnol. 2016;1(3):85-91.

17. Damade R, Cacoub P. Les hyperferritinémies. Ann Med Interne. 2000;151(3): 169-77.

18. Weiss G. Modification of iron regulation by the inflammatory response. Best Pract Res Clin Haematol. 2005:2:183-201.

19. Chapman R, Morgan R, Laulicht M, Hoffbrand A, Scherlock S. Hepatic iron store and markers of iron overload in alcocholics and patients with idiopathic hemochromatosis. Dig Dis Sci. 1982;27:909-16.

20. Porter JB. Practical management of iron overload. Br J Haematol. 2001; 115(2):239-52

21. Conrad ME, Umbreil JN, Moore EG. Iron absorption and transport. Am J Med Sci. 1999;318:213-29.

22. Lafond JI AJ. Iron metabolism. Rev Prat. 2000;50:945-9.

23. Akinbami AA, Dosunmu AO, Adediran AA, Oshinaike OO, Osunkalu VO, Ajibola SO. Serum ferritine levels in adults with sickle cell disease in Lagos, Nigeria. J Blood Med. 2013:4:59-63.

24. Tayou Tagny CT, Oloume ME, Chetcha B, Mbanya D. Serum ferritin levels in 41 multiple-transfused sickle cell patients at the Yaounde central hospital, Cameroon, Africa: a pilot study. Int J Hem Res. 2015;1(1):24-6.

25. Hafsia R, Belakhal F, Ben Salah N, Gouider E, Elborgi W. Iron overload in sickle cell anemia: a study of 94 patients. Tunis Med. 2011:89(6):548-52. 
26. Abdel Rahman HA, Abou-Elew HH, El-Shorbagy RM, Fawzy R, Youssry I. Influence of iron regulating genes mutations on iron status in Egyptian patients with sickle cell disease. Ann Clin Lab Sci. 2014;44(3):304-9.

27. Gandon Y, Olivié D, Guyader D, Aubé C, Oberti F, Sebille V, Deugnier Y. Non-invasive assessment of hepatic iron stores by MRI. Lancet. 2004;363: $357-62$

Ready to submit your research? Choose BMC and benefit from:

- fast, convenient online submission

- thorough peer review by experienced researchers in your field

- rapid publication on acceptance

- support for research data, including large and complex data types

- gold Open Access which fosters wider collaboration and increased citations

- maximum visibility for your research: over $100 \mathrm{M}$ website views per year

At BMC, research is always in progress.

Learn more biomedcentral.com/submissions 